\title{
PENGARUH SOSIALISASI PERPAJAKAN, PELAYANAN FISKUS DAN \\ PELAKSANAAN SELF ASSESSMENT SYSTEM TERHADAP TINGKAT KEPATUHAN WAJIB PAJAK ATAS PAJAK RUMAH KOS (Studi Pada Dinas Pendapatan Daerah Kota Malang)
}

\author{
Desi Astuti \\ Bety Nur Achadiyah \\ Universitas Negeri Malang
}

\begin{abstract}
Pengaruh Sosialisasi Perpajakan, Pelayanan Fiskus Dan Pelaksanaan Self Assessment System Terhadap Tingkat Kepatuhan Wajib Pajak Atas Pajak Rumah Kos (Studi Pada Dinas Pendapatan Daerah Kota Malang). Penelitian ini mengkaji tingkat kepatuhan wajib pajak orang atas pajak rumah kos di kota Malang dengan menggunakan beberapa variabel bebas seperti sosialisasi perpajakan, pelayanan fiskus, dan pelaksanaan self assessment system. Penentuan sampel ini dilakukan secara insidental, dimana apabila menjumpai wajib pajak yang dianggap sesuai, maka dijadikan sebagai responden dalam penelitian ini. Jumlah sampel ditentukan sebanyak 92 orang. Teknik pengumpulan data dalam penelitian ini menggunakan metode kuisioner yang dilakukan dengan cara memberikan seperangkat pernyataan tertulis kepada responden untuk dijawabnya. Hasil penelitian menyatakan bahwa sosialisasi perpajakan dan pelaksanaan self assessment system tidak berpengaruh signifikan terhadap kepatuhan wajib pajak atas pajak rumah kos. Sedangkan pelayanan fiskus berpengaruh positif signifikan terhadap kepatuhan wajib pajak atas pajak rumah kos
\end{abstract}

Kata Kunci: Sosialisasi Perpajakan, Pelayanan Fiskus, Self Assessment System, Pajak Rumah Kos.

\section{PENDAHULUAN}

Meningkatnya perkembangan dunia usaha di Indonesia, mendorong kemandirian dalam membiayai pembangunan nasional. Hal ini dilaksanakan dengan jalan lebih mengarahkan segenap potensi dan kemampuan dari dalam negeri, khususnya dengan cara meningkatkan penerimaan negara melalui sektor perpajakan.

Pelaksanaan UU. No. 32 tahun 2004 tentang Pemerintahan Daerah telah menyebabkan perubahan mendasar dalam pengaturan hubungan pusat dan daerah, khususnya dalam bidang administrasi pemerintahan maupun dalam hubungan keuangan antar Pemerintah Pusat dan
Pemerintah Daerah. Oleh karena itu setiap daerah diberikan kesempatan untuk dapat menggali potensi daerahnya masing-masing yang bertujuan untuk meningkatkan Pendapatan Asli Daerah (PAD), program tersebut lebih dikenal dengan nama otonomi daerah.

Otonomi daerah diharapkan dapat membantu percepatan kesejahteraan masyarakat melalui peningkatan, pelayanan, pemberdayaan dan peran-serta masyarakat, serta peningkatan daya saing daerah (Bawono \& Mochamad, 2012:1). Salah satu wewenang yang diberikan pemerintah pusat kepada daerah otonom adalah menentukan kebijakan 
pajak daerahnya masing-masing, untuk memungut dan mengelola pajak daerah.

Kota Malang dengan luas 110,06 km² merupakan kota terbesar kedua di Provinsi Jawa Timur setelah kota Surabaya. Sampai dengan Juli 2015 kota Malang memiliki jumlah penduduk mencapai 873.716 jiwa (dispendukcapil.malangkota.go.id). Malang dikenal sebagai kota pendidikan karena memiliki sekitar lebih dari 30 perguruan tinggi baik negeri maupun swasta yang mayoritas mahasiswa berasal dari luar daerah. Kondisi inilah yang menyebabkan usaha dibidang jasa rumah kos banyak dijumpai di kota ini. Pajak rumah kos ini merupakan bagian dari kategori pajak hotel yang memiliki potensi yang besar dalam peningkatan PAD kota Malang. Dengan diberlakukannya pajak rumah kos diharapkan para pendatang memiliki kontribusi dalam pembangunan daerah yang dibayarkan melalui pajak daerah yaitu pajak rumah kos.

Pajak rumah kos di kota Malang telah diatur dalam Peraturan Daerah Nomor 16 Tahun 2010 tentang Pajak Daerah. Namun, peraturan tersebut baru diterapkan pada akhir tahun 2013 karena alasan butuh banyak persiapan.

Berdasarkan peraturan tersebut telah disebutkan bahwa setiap pemilik rumah kos yang memiliki kamar di atas sepuluh diwajibkan untuk membayar pajak 5\% dari total penghasilan rumah kos dalam satu bulan.
Tabel 1.1 Jumlah Wajib Pajak

\begin{tabular}{ll}
\hline Tahun & Jumlah Wajib Pajak \\
\hline $\mathbf{2 0 1 3}$ & 16 \\
\hline $\mathbf{2 0 1 4}$ & 424 \\
\hline $\mathbf{2 0 1 5}$ & 650 \\
\hline Total & 1090 \\
\hline
\end{tabular}

Sumber: Dinas Pendapatan Daerah Kota Malang (data diolah)

Berdasarkan tabel diatas dapat diketahui bahwa jumlah wajib pajak yang terdaftar di Dinas Pendapatan Daerah Kota Malang mulai akhir tahun 2013 sampai September 2015 telah mengalami peningkatan yang signifikan. Namun, menurut Minto Raharjo selaku kepala Sub Bagian Umum Badan Perizinan Pelayanan Terpadu (BP2T) Kota Malang, banyak pengusaha rumah kos yang belum mengajukan permohonan izin. Sampai tahun 2015 masih tercatat 93 pengusaha rumah kos yang sudah menjalankan kewajibannya. Peraturan Daerah Nomor 6 Tahun 2006 telah disebutkan bahwa setiap pemilik rumah kos yang memiliki minimal sepuluh kamar di wajibkan untuk mengajukan izin ke Badan Perizinan Pelayanan Terpadu (BP2T) Kota Malang.

Selain itu, berdasarkan informasi dari website resmi Dinas Pendapatan Daerah Kota Malang wajib pajak kos masih menduduki peringkat pertama yang harus dilakukan penertiban. Dari 39 wajib pajak yang harus ditertibkan, 15 titik merupakan wajib pajak kos yang memiliki tunggakan. Dan dari 26 wajib pajak lainnya terdapat 13 wajib pajak rumah kos yang harus ditertibkan 


\section{JURNAL NOMINAL / VOLUME V NOMOR 1 / TAHUN 2016}

(dispenda.malangkota.go.id). Kondisi di atas menunjukkan tingkat kepatuhan wajib pajak rumah kos belum maksimal dan masih perlu dilakukan kajian lebih mendalam mengenai tingkat kepatuhan wajib pajak rumah kos untuk mempengaruhi kemauan dan kepatuhan wajib pajak dalam melaksanakan kewajiban perpajakan yang terdapat di Kota Malang.

Kaitannya dengan kepatuhan wajib pajak ini, maka Theory of Planned Behavior yang mendasarkan asumsi bahwa manusia adalah makhluk yang rasional dan menggunakan informasi-informasi yang mungkin baginya, secara sistematis. Orang memikirkan implikasi dari tindakan mereka sebelum mereka memutuskan untuk melakukan atau tidak melakukan perilaku-perilaku tertentu.

Menurut Teori Pembelajaran Sosial, seseorang (wajib pajak) dapat belajar lewat pengamatan dan pengalaman langsung. Proses pembelajaran sosial meliputi: proses perhatian, penahanan, reprodukdi motorik dan penguatan yang relevan untuk menjelaskan variabel sosialisasi perpajakan, pelayanan fiskus dan pelaksanaan Self Assessment System.

Menurut penelitian Winerungan (2013), sosialisasi perpajakan tidak berpengaruh terhadap kepatuhan Wajib Pajak Orang Pribadi di KPP Pratama Manado dan KPP Pratama Bitung. Penelitian Ahsin (2012), juga menyimpulkan bahwa pemberian sosialisasi pajak bangunan kurang berpengaruh terhadap kepatuhan wajib pajak.
Berbeda dengan penelitian yang dilakukan Setiyoningrum,dkk (2014), menyatakan bahwa terdapat pengaruh sosialisasi perpajakan terhadap kepatuhan wajib pajak orang pribadi.

Sedangkan menurut penelitian Setiyoningrum, dkk (2014), variabel pelayanan fiskus diketahui tidak berpengaruh terhadap kepatuhan wajib pajak orang pribadi. Hal yang sama juga disimpulkan oleh Winerungan (2013), bahwa kualitas pelayanan tidak berpengaruh terhadap kepatuhan wajib pajak orang pribadi. Sedangkan penelitian Windurisasi dalam Boediono (1999:154) menyatakan bahwa ada hubungan yang positif antara kualitas pelayanan dengan kepatuhan wajib pajak. Dengan demikian, keberhasilan instansi pajak memberikan kualitas pelayanan sesuai dengan harapan pelanggan dapat meningkatkan kepatuhan wajib pajak.

Melihat kondisi dan adanya research gap dari penelitian-penelitian terdahulu, memberikan motivasi penulis untuk menguji kembali variabel-variabel tersebut dalam bentuk skripsi dengan judul :

"Pengaruh Sosialisasi Perpajakan, Pelayanan Fiskus dan Pelaksanaan Self Assessment System Terhadap Tingkat Kepatuhan Wajib Pajak Atas Pajak Rumah Kos (Studi Pada Dinas Pendapatan Daerah Kota Malang)". 


\section{METODE PENELITIAN}

\section{Rancangan Penelitian}

Jenis penelitian yang digunakan adalah eksplanatory research, yaitu penelitian yang menjelaskan hubungan kausal antara variabel-variabel melalui pengujian hipotesa (Masri dan Efendi, 1995:5). Variabel bebas dalam penelitian ini adalah sosialisasi perpajakan $\left(\mathrm{X}_{1}\right)$, pelayanan fiskus $\left(\mathrm{X}_{2}\right)$ dan pelaksanaan Self Assessment System $\left(\mathrm{X}_{3}\right)$. Sedangkan variabel terikat yang digunakan adalah tingkat kepatuhan wajib pajak (Y).

\section{Populasi dan Sampel}

Populasi dalam penelitian ini adalah Wajib Pajak atas rumah Kos yang telah terdaftar di Dinas Pendapatan Daerah Kota Malang pada akhir tahun 2013 sampai tahun 2015 sejumlah 1090 wajib pajak.

Pengambilan sampel yang digunakan dalam penelitian ini adalah teknik insidential sampling. Insidential sampling adalah teknik penentuan sampel berdasarkan kebetulan, yaitu siapa saja yang secara kebetulan/insidental bertemu dengan peneliti dapat digunakan sebagai sampel, bila dipandang orang yang kebetulan ditemui itu cocok sebagai sumber data (Sugiyono:2010:124). Penentuan jumlah sampel dalam penelitian ini menggunakan pendek atau Slovin dengan rumus:

$$
\mathrm{n}=\frac{\mathrm{N}}{1+\mathrm{N} \cdot \mathrm{e}^{2}}
$$

\section{Dimana :}

$\mathrm{n} \quad=$ Ukuran Sampel

$\mathrm{N} \quad=$ Ukuran Populasi

e $=$ Persentasi kelonggaran ketidaktelitian karena kesalahan pengambilan sampel yang masih dapat ditolerir (dalam penelitian ini 10\%)

$$
\begin{aligned}
\mathrm{n} & =\frac{1090}{1090 \cdot(0,1)^{2}+1} \\
& =91.59 / 92 \text { sampel (dibulatkan) }
\end{aligned}
$$

Sumber : Suharso, (2010:63)

Berdasarkan perhitungan tersebut, maka jumlah sampel dengan ukuran populasi sebanyak 1090 wajib pajak kos di Dinas Pendapatan Daerah Kota Malang diperoleh sebanyak 92 sampel untuk diteliti.

\section{Instrumen Penelitian}

Instrumen penelitian yang digunakan adalah angket atau kuisioner. Sukandarrumidi (2012:78) menyatakan bahwa " kuisioner disebut pula angket atau self administrated questioner adalah teknik pengumpulan data dengan cara mengirimkan suatu daftar pertanyaan kepada responden untuk diisi Jenis kuisioner yang digunakan dalam penelitian ini adalah kuisioner tertutup, dimana jawaban telah disediakan untuk setiap pertanyaan atau pernyataan dari angket ini, sehingga responden cukup memlih alternatif jawaban yang telah tersedia.

Untuk menguji variabel independen dalam penelitian ini menggunakan skala likert. Skala likert adalah skala interval yang 
secara spesifik menggunakan empat pilihan, yaitu sangat setuju, setuju, tidak setuju dan sangat tidak setuju.

Tabel 3.1 Kisi-Kisi Angket

\begin{tabular}{|c|c|c|c|c|}
\hline Variabel & $\begin{array}{l}\text { Sub } \\
\text { Variab } \\
\text { el }\end{array}$ & Indikator & $\begin{array}{l}\text { Juml } \\
\text { ah } \\
\text { perta } \\
\text { nyaa } \\
\text { n }\end{array}$ & $\begin{array}{l}\text { Nom } \\
\text { or } \\
\text { Butir } \\
\text { Perta } \\
\text { nyaa } \\
\text { n }\end{array}$ \\
\hline $\begin{array}{l}\text { Sosialisasi } \\
\text { perpajakan } \\
\text { (Putri, } \\
\text { 2013) }\end{array}$ & $\begin{array}{l}\text { - Sosial } \\
\text { isasi } \\
\text { langs } \\
\text { ung } \\
\text { - Sosial } \\
\text { isasi } \\
\text { tidak } \\
\text { langs } \\
\text { ung }\end{array}$ & $\begin{array}{l}\text { - Penyuluh } \\
\text { an } \\
\text { - Diskusi } \\
\text { dengan } \\
\text { wajib } \\
\text { pajak dan } \\
\text { tokoh } \\
\text { masyara } \\
\text { kat } \\
\text { - Informas } \\
\text { i } \\
\text { langsung } \\
\text { dari } \\
\text { petugas } \\
\text { ke wajib } \\
\text { pajak } \\
\text { - Pemasan } \\
\text { gan } \\
\text { billboard } \\
\text { - Web site } \\
\text { Ditjen } \\
\text { pajak }\end{array}$ & 6 & $\begin{array}{l}1,2, \\
3,4, \\
5,6\end{array}$ \\
\hline $\begin{array}{l}\text { Pelayanan } \\
\text { fiskus } \\
\text { (Brady\&Cr } \\
\text { onin,2006; } \\
\text { Aryobimo, } \\
\text { 2012,Jatmi } \\
\text { ko, } \\
\text { 2006) }\end{array}$ & $\begin{array}{l}\text { - Kualit } \\
\text { as } \\
\text { Pelay } \\
\text { anan } \\
\text { Fisku } \\
\text { s }\end{array}$ & $\begin{array}{l}\text { - Pelayana } \\
\text { n yang } \\
\text { diberikan } \\
\text { - Kualitas } \\
\text { SDM } \\
\text { - Pemaha } \\
\text { man } \\
\text { terhadap } \\
\text { ketentua } \\
\text { n } \\
\text { perpajak } \\
\text { an } \\
\text { - Sistem } \\
\text { informas } \\
\text { i } \\
\text { perpajak } \\
\text { an } \\
\text { - Kualitas } \\
\text { lingkung } \\
\text { an kantor } \\
\text { pajak. }\end{array}$ & 8 & $\begin{array}{l}7,8, \\
9,10, \\
11, \\
12, \\
13, \\
14\end{array}$ \\
\hline
\end{tabular}

\begin{tabular}{|c|c|c|c|c|}
\hline $\begin{array}{l}\text { Pelaksanaa } \\
\text { n Self } \\
\text { Assessment } \\
\text { (Ning } \\
\text { Wahyuni, } \\
\text { 2013) }\end{array}$ & $\begin{array}{l}\text { - Pelak } \\
\text { sanaa } \\
\mathrm{n} \text { Self } \\
\text { Asses } \\
\text { sment } \\
\text { syste } \\
\text { m }\end{array}$ & $\begin{array}{l}\text { - Mendaft } \\
\text { arkan diri } \\
\text { di Kantor } \\
\text { Pelayana } \\
\text { n Pajak. } \\
\text { - Menghit } \\
\text { ung dan } \\
\text { atau } \\
\text { memperh } \\
\text { itungkan } \\
\text { sendiri } \\
\text { jumlah } \\
\text { pajak } \\
\text { yang } \\
\text { terutang. } \\
\text { - Menyeto } \\
\text { r pajak } \\
\text { tersebut } \\
\text { ke bank } \\
\text { persepsi/ } \\
\text { kantor } \\
\text { pos. } \\
\text { - Melapor } \\
\text { kan } \\
\text { penyetor } \\
\text { an } \\
\text { tersebut } \\
\text { kepada } \\
\text { Direktur } \\
\text { Jenderal } \\
\text { Pajak. } \\
\text { - Menetap } \\
\text { kan } \\
\text { sendiri } \\
\text { jumlah } \\
\text { pajak } \\
\text { yang } \\
\text { terutang } \\
\text { melalui } \\
\text { pengisia } \\
\text { n SPTPD } \\
\text { (Surat } \\
\text { Pemberit } \\
\text { ahuan) } \\
\text { dengan } \\
\text { baik dan } \\
\text { benar }\end{array}$ & 9 & $\begin{array}{l}15, \\
16, \\
17, \\
18, \\
19, \\
20, \\
21, \\
22, \\
23,\end{array}$ \\
\hline $\begin{array}{l}\text { Kepatuhan } \\
\text { Wajib } \\
\text { Pajak Kos } \\
\text { (Agustin, } \\
\text { 2015) }\end{array}$ & $\begin{array}{l}\text { - Kepat } \\
\text { uhan } \\
\text { Form } \\
\text { al } \\
\text { - Kepat } \\
\text { uhan } \\
\text { Mater } \\
\text { ial }\end{array}$ & $\begin{array}{l}\text { - Ketepata } \\
\mathrm{n} \\
\text { memenu } \\
\text { hi } \\
\text { kewajiba } \\
\mathrm{n} \\
\text { perpajak } \\
\text { an } \\
\text { - Ketepata } \\
\text { n dan } \\
\text { kejujuran } \\
\text { dalam } \\
\text { menyam }\end{array}$ & 12 & $\begin{array}{l}24, \\
25, \\
26, \\
27, \\
28, \\
29, \\
30, \\
31, \\
32, \\
33, \\
34, \\
35\end{array}$ \\
\hline
\end{tabular}




\section{JURNAL NOMINAL / VOLUME V NOMOR 1 / TAHUN 2016}

\begin{tabular}{ll}
\hline paikan & Surat \\
& Pemberit \\
ahuan & Pajak \\
& Daerah \\
& (SPTPD) \\
- & Membay \\
& ar pajak \\
& dengan \\
& tepat \\
& waktu \\
- & Tidak \\
& memiliki \\
& tunggaka \\
& n \\
- Konsulta \\
si dengan \\
petugas \\
pajak \\
- Tidak \\
pernah \\
dipidana \\
dalam \\
bidang \\
perpajak \\
an. \\
- Bersedia \\
memenu \\
hi sanksi \\
bila \\
terjadi \\
kesalaha \\
n. \\
\hline
\end{tabular}

Instrumen dikembangkan untuk menjaring data yang berkaitan dengan masalah yang diteliti. Oleh karena data yang diperoleh dari penyebaran angket ini adalah kuantitatif, maka setiap jawaban responden diberi skor untuk mengubah data tersebut menjadi kuantitatif. Pemberian skor untuk pertanyaan yang telah disediakan adalah

$$
\begin{array}{ll}
\mathrm{SS} & =\text { sangat setuju } \\
\mathrm{S} & =\text { setuju } \\
\mathrm{TS} & =\text { tidak setuju } \\
\mathrm{STS} & =\text { sangat tidak setuju }
\end{array}
$$

\section{Jenis Data dan Sumber Data}

Jenis data yang digunakan dalam penelitian ini adalah data kuantitatif. Data kuantitatif dalam penelitian ini adalah data yang diperoleh dari hasil kuisioner atau angket responden yang diuraikan dalam bentuk angka. Sedangkan sumber data untuk penelitian ini diperoleh dari data primer dan data sekunder. Sumber data primer dalam penelitian ini adalah berasal dari kuisioner yang telah disebar kepada wajib pajak rumah kos yang telah terdaftar di Dinas Pendapatan Daerah Kota Malang.

Sumber data sekunder dari penelitian ini diperoleh dari beberapa literatur, artikel, jurnal, peraturan-peraturan perpajakan, menggunakan media informasi internet dan data-data yang diperoleh dari Dinas Pendapatan Daerah Kota Malang.

\section{Teknik Pengumpulan Data}

Teknik pengumpulan data dalam penelitian ini adalah menggunakan metode kuisioner. Peneliti akan memberikan sejumlah pertanyaan kepada wajib pajak yang terdaftar di Dinas Pendapatan Daerah Kota Malang dengan media kuisioner dan wajib pajak diminta untuk merespon.

\section{bobot 4 Tempat Penelitian.}

bobot 3 Tempat yang digunakan untuk bobot 2 melaksanakan penelitian adalah Dinas bobot 1 Pendapatan Daerah Kota Malang dengan alamat Kantor Pelayanan Terpadu Pemerintah Kota Malang Gedung B Lantai 1, Jl. Mayjen 
Sungkono, Jawa Timur 65132 Phone:(0341) 751532.

\section{Analisis Data}

Analisis data yang digunakan dalam penelitian ini adalah model analisis regresi linear berganda. Tujuan penggunaan analisis regresi linear berganda adalah untuk menguji pengaruh dari dua atau lebih variabel bebas dari kesalahan bias. Analisis data akan dilakukan dengan bantuan program aplikasi Statistical Package For Sosial Science (SPSS) 19 dalam empat tahap. Tahap pertama, pengujian kualitas data. Tahap kedua melakukan uji penyimpangan asumsi klasik. Tahap ketiga, melakukan analisis regresi. Dan tahap keempat, melakukan uji hipotesis.

\section{HASIL}

1. Sosialisasi Perpajakan.

Tabel 4.1 Distribusi Frekuensi Pengaruh Sosialisasi Perpajakan

\begin{tabular}{lllll}
\hline No & $\begin{array}{l}\text { Kelas } \\
\text { Interval }\end{array}$ & Kriteria & Frekuensi & $\%$ \\
\hline $\mathbf{1}$ & $6-10$ & $\begin{array}{l}\text { Sangat } \\
\text { tidak } \\
\text { setuju }\end{array}$ & 0 & $0 \%$ \\
\hline $\mathbf{2}$ & $11-15$ & $\begin{array}{l}\text { Tidak } \\
\text { setuju }\end{array}$ & 71 & $77 \%$ \\
\hline $\mathbf{3}$ & $16-20$ & Setuju & 20 & $22 \%$ \\
\hline $\mathbf{4}$ & $21-25$ & $\begin{array}{l}\text { Sangat } \\
\text { setuju }\end{array}$ & 1 & $1 \%$ \\
\hline Total & & 92 & $100 \%$ \\
\hline
\end{tabular}

Dari tabel 4.1, dapat dilihat bahwa tidak ada wajib pajak atas pajak rumah kos yang sangat tidak setuju terhadap sosialisasi perpajakan. Wajib pajak atas pajak rumah kos memiliki pendapat tidak setuju sebesar $77 \%$, sedangkan $22 \%$ wajib pajak atas pajak rumah kos menjawab setuju, dan $1 \%$ wajib pajak atas pajak rumah kos sangat setuju terhadap sosialisasi perpajakan. Berdasarkan hasil statistik (lampiran7) diperoleh nilai rata-rata (mean) sebesar 14,34 orang. Nilai tersebut berada pada interval 11 - 15 dengan kualifikasi tidak setuju. Berdasarkan hasil tersebut dapat diperoleh gambaran bahwa wajib pajak atas pajak rumah kos di Dinas Pendapatan daerah Kota Malang memiliki pendapat tidak setuju terhadap sosialisasi perpajakan.

\section{Pelayanan Fiskus}

Tabel 4.2 Distribusi Frekuensi Pelayanan Fiskus

\begin{tabular}{lclll}
\hline No & $\begin{array}{l}\text { Kelas } \\
\text { Interval }\end{array}$ & Kriteria & Frekuensi & $\%$ \\
\hline $\mathbf{1}$ & $8-13$ & $\begin{array}{l}\text { Sangat } \\
\text { tidak } \\
\text { setuju }\end{array}$ & 0 & $0 \%$ \\
\hline $\mathbf{2}$ & $14-19$ & $\begin{array}{l}\text { Tidak } \\
\text { setuju }\end{array}$ & 6 & $6 \%$ \\
\hline $\mathbf{3}$ & $20-25$ & Setuju & 43 & $47 \%$ \\
\hline $\mathbf{4}$ & $26-32$ & $\begin{array}{l}\text { Sangat } \\
\text { setuju }\end{array}$ & 43 & $47 \%$ \\
\hline Total & & 92 & $100 \%$ \\
\hline
\end{tabular}

Dari tabel 4.2, dapat dilihat bahwa tidak ada wajib pajak atas pajak rumah kos yang sangat tidak setuju terhadap pelayanan fiskus. Wajib pajak atas pajak rumah kos memiliki pendapat tidak setuju sebesar $6, \%$, sedangkan untuk pendapat setuju dan sangat setuju masing-masing sebesar $47 \%$. Berdasarkan hasil statistik (lampiran 7) diperoleh nilai rata-rata (mean) sebesar 25,01 orang. Nilai tersebut berada pada interval 20 - 25 dengan kualifikasi setuju. Berdasarkan hasil tersebut 
dapat diperoleh gambaran bahwa wajib pajak atas pajak rumah kos di Dinas Pendapatan daerah Kota Malang memiliki pendapat setuju terhadap pelayanan fiskus.

\section{Pelaksanaan Self Assessment System.}

Tabel 4.3 Distribusi Frekuensi Pelaksanaan Self Assessment System

\begin{tabular}{|c|c|c|c|c|}
\hline No & $\begin{array}{l}\text { Kelas } \\
\text { Interval }\end{array}$ & Kriteria & Frekuensi & $\%$ \\
\hline 1 & $9-15$ & $\begin{array}{l}\text { Sangat } \\
\text { tidak } \\
\text { setuju }\end{array}$ & 0 & $0 \%$ \\
\hline 2 & $16-22$ & $\begin{array}{l}\text { Tidak } \\
\text { setuju }\end{array}$ & 61 & $66 \%$ \\
\hline 3 & $23-29$ & Setuju & 30 & $33 \%$ \\
\hline 4 & $30-36$ & $\begin{array}{l}\text { Sangat } \\
\text { setuju }\end{array}$ & 1 & $1 \%$ \\
\hline \multicolumn{2}{|c|}{ Total } & & 92 & $100 \%$ \\
\hline
\end{tabular}

Dari tabel 4.3, dapat dilihat bahwa tidak ada wajib pajak atas pajak rumah kos yang sangat tidak setuju terhadap pelaksanaan Self Assessment System. Tetapi Wajib pajak atas pajak rumah kos yang memiliki pendapat tidak setuju sebesar 66\%, sedangkan 33\% wajib pajak atas pajak rumah kos menjawab setuju, dan sisanya $1 \%$ wajib pajak atas pajak rumah kos sangat setuju terhadap pelaksanaan Self Assessment System. Berdasarkan hasil statistik (lampiran 7) diperoleh nilai rata-rata (mean) sebesar 21,61 orang dibulatkan menjadi 22 orang. Nilai tersebut berada pada interval 16 - 22 dengan kualifikasi tidak setuju. Berdasarkan hasil tersebut dapat diperoleh gambaran bahwa wajib pajak atas pajak rmah kos di Dinas Pendapatan daerah Kota Malang memiliki pendapat tidak setuju terhadap pelaksanaan Self Assessment System.

\section{Kepatuhan Wajib Pajak}

Tabel 4.4 Distribusi Frekuensi Kepatuhan Wajib Pajak

\begin{tabular}{lllll}
\hline No & $\begin{array}{l}\text { Kelas } \\
\text { Interval }\end{array}$ & Kriteria & Frekuensi & $\%$ \\
\hline $\mathbf{1}$ & $12-20$ & $\begin{array}{l}\text { Sangat } \\
\text { tidak } \\
\text { setuju }\end{array}$ & 0 & $0 \%$ \\
\hline $\mathbf{2}$ & $21-29$ & $\begin{array}{l}\text { Tidak } \\
\text { setuju }\end{array}$ & 3 & $3 \%$ \\
\hline $\mathbf{3}$ & $30-38$ & Setuju & 49 & $53 \%$ \\
\hline $\mathbf{4}$ & $39-48$ & $\begin{array}{l}\text { Sangat } \\
\text { setuju }\end{array}$ & 40 & $44 \%$ \\
\hline \multicolumn{2}{l}{ Total } & & 92 & $100 \%$ \\
\hline
\end{tabular}

Dari tabel 4.4, dapat dilihat bahwa tidak ada wajib pajak atas pajak rumah kos yang sangat tidak setuju terhadap kepatuhan wajib pajak. Sebanyak 3\% wajib pajak atas pajak rumah kos menjawab tidak setuju, 53\% wajib pajak atas pajak rumah kos menjawab setuju, dan $44 \%$ wajib pajak atas pajak rumah kos sangat setuju terhadap kepatuhan wajib pajak. Berdasarkan hasil statistik (lampiran 7) diperoleh nilai rata-rata (mean) sebesar 38,01 orang. Nilai tersebut berada pada interval 30 - 38 dengan kualifikasi setuju. Berdasarkan hasil tersebut dapat diperoleh gambaran bahwa wajib pajak atas pajak rumah kos di Dinas Pendapatan daerah Kota Malang memiliki pendapat setuju terhadap kepatuhan wajib pajak. 


\section{a. Hasil Uji Normalitas}

Tabel 4.5 Hasil Uji Normalitas Data

One-Sample Kolmogorov-Smirnov Test

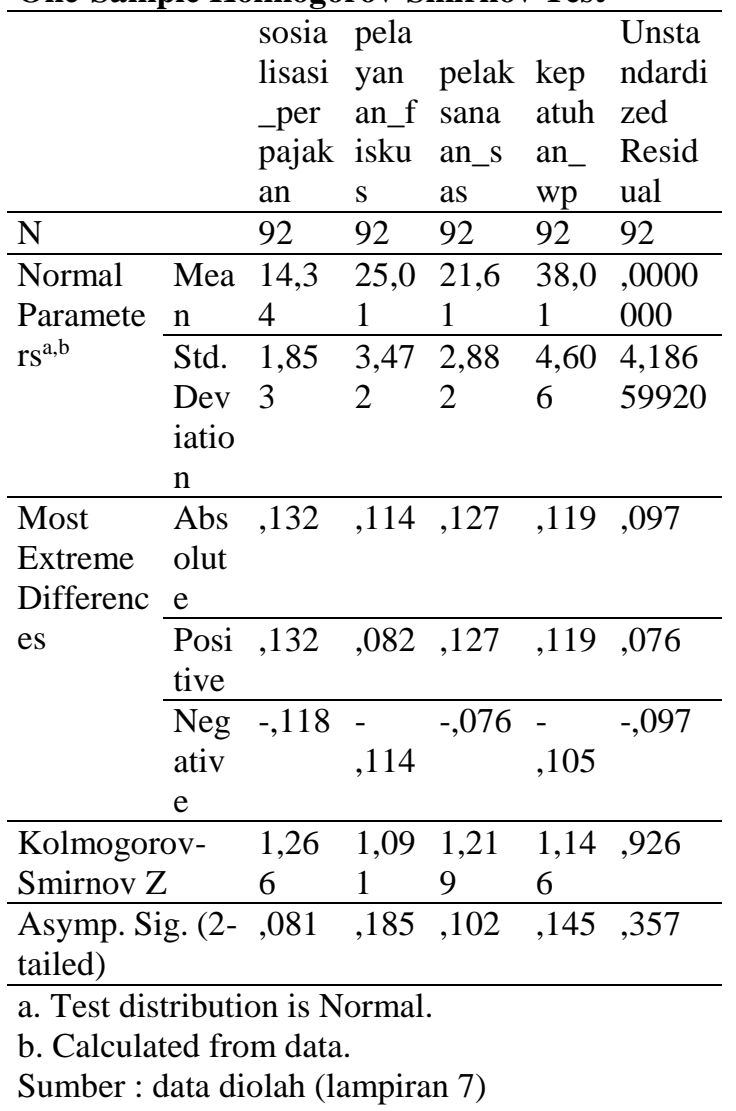

Hasil uji normalitas pada tabel 4.5 di atas didapatkan nilai signifikansi dari uji K-S sebesar 0,081 untuk variabel sosialisasi perpajakan, 0,185 untuk variabel pelayanan fiskus, dan 0,102 untuk variabel pelaksanaan Self Assessment System dan 0,145 untuk variabel kepatuhan wajib pajak. Angkaangka tersebut lebih tinggi dibandingkan taraf signifikansi $5 \%$ (0.05). Hal tersebut memberikan gambaran bahwa data yang terdapat dalam penelitian ini berdistribusi normal.

\section{b. Hasil Uji Multikolinearitas}

Tabel 4.6 Hasil Uji Multikolinearitas Data Coefficients $^{\mathrm{a}}$

\begin{tabular}{llll}
\hline \multirow{2}{*}{ Model } & \multicolumn{2}{l}{ Collinearity Statistics } \\
\cline { 2 - 4 } & & Tolerance & VIF \\
\hline 1 & (Constant) & & \\
\cline { 2 - 4 } & sosialisasi_perpajakan &, 938 & 1,066 \\
\cline { 2 - 4 } & pelayanan_fiskus &, 933 & 1,072 \\
\hline pelaksanaan_sas &, 993 & 1,007 \\
\hline
\end{tabular}

a. Dependent Variable: kepatuhan_wp

Sumber : data diolah (lampiran 7)

Berdasarkan tabel 4.6, pengujian menghasilkan nilai Tolerance lebih besar dari 0,1 dan nilai VIF kurang dari 10 pada keseluruhan variabel penelitian. Berdasarkan hasil tersebut dapat disimpulkan tidak terdapat gejala multikolinearitas yang serius antar variabel independen dalam model regresi.

\section{c. Hasil Uji Heteroskedastisitas}

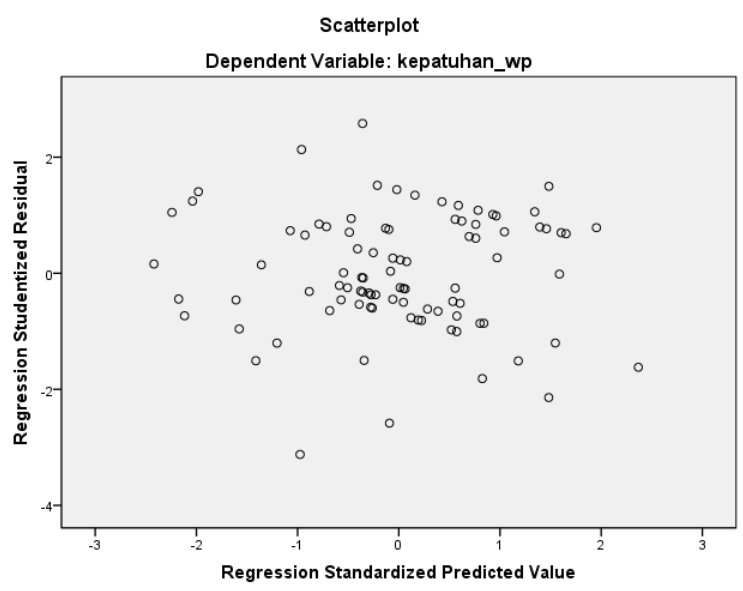

Gambar 4.1 Uji Heteroskedastisitas

Dari gambar 4.1 menunjukkan bahwa titiktitik menyebar di atas dan di bawah angka 0 pada sumbu $\mathrm{Y}$ dan tidak mempunyai pola yang jelas atau trend garis tertentu. Dari hasil gambar tersebut dapat diambil kesimpulan bahwa tidak terjadi heteroskedastisitas dan 


\section{JURNAL NOMINAL / VOLUME V NOMOR 1 / TAHUN 2016}

model regresi layak dipakai asumsi untuk memenuhi persayaratan analisis. Sehingga penaksiran koefisien-koefisien regresi akan menjadi efisien.

Tabel 4.7 Hasil Uji Regresi Berganda tabel Coeficient $^{\mathrm{a}}$

Coefficients $^{\mathrm{a}}$

\begin{tabular}{|c|c|c|c|c|c|c|}
\hline \multirow[t]{2}{*}{ Model } & \multicolumn{2}{|c|}{ 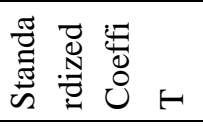 } & \multicolumn{4}{|c|}{ 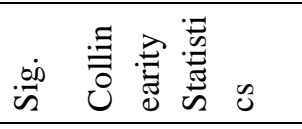 } \\
\hline & $\stackrel{\pi}{0}$ & & & 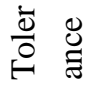 & $\stackrel{|c|}{>}$ & \\
\hline 1 泀 & & $\underset{\substack{+ \\
\text { n }}}{ }$ & $\tilde{\delta}$ & & & \\
\hline 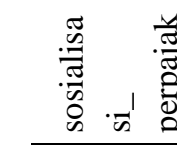 & $\overbrace{0}^{\infty}$ & $\frac{n}{n}$ & $\stackrel{\infty}{?}$ & $\stackrel{\infty}{\sigma}$ & & 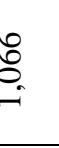 \\
\hline 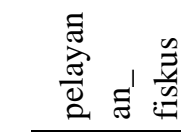 & $\bar{F}$ & $\begin{array}{l}\hat{a} \\
\hat{o} \\
\hat{f}\end{array}$ & 8 & $\tilde{\sigma}$ & & S. \\
\hline 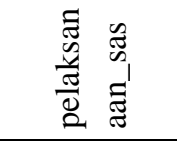 & $\stackrel{\infty}{5}$ & వి. & $\underset{\mathcal{I}}{\stackrel{f}{*}}$ & $\hat{\sigma}$ & & $\underline{8}$ \\
\hline
\end{tabular}

a. Dependent Variable: kepatuhan_wp

Sumber : data diolah (lampiran 8)

Berdasarkan hasil uji regresi pada tabel di atas, model regresi yang terbentuk dapat dijabarkan dalam persamaan berikut :

$$
\mathrm{Y}=20,326+0,093 \mathrm{X}_{1}+0,545 \mathrm{X}_{2}+
$$

\section{$0,125 \times 3+6,274 \mathrm{e}$}

Koefisien Determinasi $\left(\mathrm{R}^{2}\right)$

Tabel 4.8 Hasil Uji Koefisien determinasi $\left(\mathrm{R}^{2}\right)$

\begin{tabular}{lllll}
\multicolumn{5}{l}{ Model Summary } \\
\hline $\mathrm{M}$ & $\mathrm{R}$ & $\mathrm{R}$ & $\begin{array}{l}\text { Adjusted R } \\
\text { S }\end{array}$ & $\begin{array}{l}\text { Std. Error of } \\
\text { the Estimate }\end{array}$ \\
$\mathrm{de}$ & & $\mathrm{S} q u a r$ & Square & \\
1 & & $\mathrm{e}$ & & \\
\hline 1 &, 41 &, 174 &, 146 & 4,257 \\
& $7^{\mathrm{a}}$ & & & \\
\hline
\end{tabular}

Berdasarkan tabel di atas dapat dilihat bahwa nilai $R$ Square dari persamaan regresi untuk menguji hipotesis penelitian adalah sebesar 0,174 atau $17,4 \%$. Hal ini berarti bahwa variabel independen dalam penelitian ini yaitu sosialisasi perpajakan, pelayanan fiskus dan pelaksanaan Self Assessment System hanya mampu menjelaskan $17,4 \%$ variabel dependen, yaitu kepatuhan wajib pajak. Sedangkan, 82,6\% lainnya dipengaruhi oleh sebab-sebab lain di luar penelitian ini. Meskipun nilai $R$ Square kecil tetapi tidak menunjukkan tanda negatif sehingga variabel independen tetap dapat menjelaskan variabel dependen. Hal ini dapat disebabkan karena Peraturan Daerah Kota Malang Nomor 16 Tahun 2010 tentang pajak rumah kos masih berjalan kurang lebih dua tahun, sehingga masih banyak wajib pajak yang kurang paham mengenai peraturan ini.

\section{Hasil Uji Hipotesis Parsial (t-test)}

1. Terdapat pengaruh positif sosialisasi perpajakan terhadap tingkat kepatuhan wajib pajak atas pajak rumah kos.

Berdasarkan hasil regresi pada tabel 4.7, dapat diketahui bahwa secara parsial sosialisasi perpajakan memiliki nilai signifikansi sebesar 0,708. Dengan demikian, nilai signifikansi lebih besar dari $\alpha=0,05$, maka tidak terdapat pengaruh secara parsial antara sosialisasi perpajakan terhadap kepatuhan wajib 


\section{JURNAL NOMINAL / VOLUME V NOMOR 1 / TAHUN 2016}

pajak atas pajak rumah kos sehingga $\mathrm{H} 1$ ditolak.

2. Terdapat pengaruh positif pelayanan fiskus terhadap tingkat kepatuhan wajib pajak atas pajak rumah kos.

Berdasarkan hasil regresi pada tabel 4.8, dapat diketahui bahwa secara parsial pelayanan fiskus memiliki nilai signifikansi sebesar 0,000. Dengan demikian, nilai signifikansi lebih kecil dari $\alpha=0,05$, maka terdapat pengaruh positif signifikan antara pelayanan fiskus terhadap kepatuhan wajib pajak atas pajak rumah kos sehingga $\mathrm{H} 2$ diterima.

3. Terdapat pengaruh positif pelaksanaan Self Assesment System terhadap tingkat kepatuhan wajib pajak atas pajak rumah kos.

Berdasarkan hasil regresi pada tabel 4.7, dapat diketahui bahwa secara parsial pelaksanaan Self Assessment System memiliki nilai signifikansi sebesar 0,422. Dengan demikian, nilai signifikansi lebih besar dari $\alpha=0,05$, maka tidak terdapat pengaruh secara parsial antara pelaksanaan Self Assessment System terhadap kepatuhan wajib pajak atas pajak rumah kos sehingga $\mathrm{H} 3$ ditolak.

\section{PEMBAHASAN}

Hasil penelitian yang pertama menyatakan bahwa variabel sosialisasi perpajakan tidak berpengaruh signifikan terhadap variabel kepatuhan wajib pajak atas pajak rumah kos. Hal tersebut disebabkan karena pajak rumah kos masih kategori pajak baru, yang mulai diterapkan pada akhir tahun 2013 dan kekuatan payung hukumnya belum terlalu kuat, sehingga masyarakat masih ragu-ragu untuk membayar pajak kos. Peraturan Daerah Kota Malang Nomor 16 Tahun 2010 hanya menyebutkan objek pajak kos yang harus membayar pajak adalah yang memiliki kamar di atas sepuluh. Menurut informasi dari wajib pajak rumah kos, minimnya peraturan tentang pajak kos ini menyebabkan sosisalisasi yang dilakukan dianggap belum maksimal. Berdasarkan hasil wawancara diketahui bahwa wajib pajak kos rata-rata mengatakan tidak mendapatkan sosialisasi dari Dinas Pendapatan Daerah Kota Malang tentang pajak rumah kos ini. Mereka langsung didatangi petugas pajak untuk didata, jika memiliki kamar kos lebih dari 10 langsung ditetapkan pajak terutang yang harus dibayar. Sebagian wajib pajak mengetahui informasi pajak rumah kos ini hanya dari stasiun televisi lokal dan media cetak lokal pada awal penerapan pajak rumah kos saja. Media sosialisasi lain seperti billboard atau spanduk tidak pernah dilihat. Padahal media sosialisasi semacam itu dianggap efektif dan efisien. Penyuluhan kepada pengusaha rumah kos juga belum diterapakan secara maksimal. Untuk itu perlu diadakannya penyuluhan pajak secara berkala, mengadakan berbagai acara yang berkaitan dengan pajak rumah kos 


\section{JURNAL NOMINAL / VOLUME V NOMOR 1 / TAHUN 2016}

serta meningkatkan media sosialisasi supaya informasi pajak rumah kos ini dapat tersampaikan dengan baik kepada masyarakat.

Hasil penelitian yang kedua menyatakan bahwa variabel pelayanan fiskus berpengaruh positif signifikan terhadap variabel kepatuhan wajib pajak atas pajak rumah kos. Hal ini dapat disimpulkan bahwa petugas pajak di Dinas Pendapatan Daerah Kota Malang telah memberikan pelayanan yang memuaskan kepada wajib pajak. Kualitas SDM yang sangat memadai karena petugas pajak merupakan lulusan perguruan tinggi yang memiliki kompetensi dalam arti memiliki keahlian, pengetahuan, dan pengalaman dalam hal kebijakan perpajakan, administrasi pajak dan peraturan perundang-undangan perpajakan. Dinas Pendapatan Daerah Kota Malang juga telah menempatkan salah satu petugas pajak yang bertugas untuk menerima keluhan, saran dan kritik dari wajib pajak. Selain itu suasana kantor yang nyaman dan kondusif membuat wajib pajak tidak merasa bosan meskipun harus mengantri lama. Untuk meningkatkan kepuasan wajib pajak atas kualitas pelayanan yang diberikan fiskus maka ketetentuan perpajakan yang ada di Dispenda harus dibuat sederhana, mudah dipahami, efektif dan efisien.

Penelitian yang ketiga ini menyatakan bahwa variabel pelaksanaan Self Assessment System tidak berpengaruh signifikan terhadap variabel kepatuhan wajib pajak atas pajak rumah kos. Hal tersebut disebabkan karena kurangnya pengetahuan dan pemahaman wajib pajak kos tentang sistem perpajakan dan ketentuan perpajakan yang berlaku. Selain itu letak kantor Dinas Pendapatan Daerah Kota Malang yang berada di pinggiran kota Malang dijadikan alasan wajib pajak untuk menunggak pajak. Banyak wajib pajak yang lebih senang menunggak dua atau tiga bulan sekali baru membayar pajak dengan alasan lebih menghemat biaya dan waktu. Untuk itu perlu adanya monitoring yang rutin dari petugas pajak supaya pelaksanaan Self Assessment System ini dapat berjalan dengan baik. Untuk itu Dispenda seharusnya mengadakan layanan membayar pajak keliling supaya memudahkan wajib pajak dalam membayar pajak.

\section{PENUTUP}

\section{Kesimpulan}

Berdasarkan hasil analisis data yang telah dilakukan dapat diperoleh kesimpulan bahwa:

1. Variabel sosialisasi perpajakan tidak berpengaruh signifikan terhadap kepatuhan wajib pajak rumah kos di kota Malang. Hal ini dikarenakan wajib pajak belum mendapatkan sosialisasi tentang pajak kos, melainkan petugas datang ke lokasi untuk melakukan pendataan dan mengirim surat kepada wajib pajak tentang peraturan pajak kos.

2. Variabel pelayanan fiskus berpengaruh positif signifikan terhadap kepatuhan 


\section{JURNAL NOMINAL / VOLUME V NOMOR 1 / TAHUN 2016}

wajib pajak rumah kos di kota Malang, ini menunjukkan bahwa kualitas pelayanan fiskus di Dinas Pendapatan Daerah Kota Malang sudah baik sehingga mendorong kepatuhan wajib pajak untuk taat.

3. Variabel pelaksanaan Self Assessment System tidak berpengaruh signifikan terhadap kepatuhan wajib pajak rumah kos di kota Malang. Hal ini dikarenakan pengetahuan dan pemahaman wajib pajak kos tentang Self Assessment System masih kurang.

\section{Keterbatasan Penelitian}

Penelitian ini hanya menggunakan variabel sosialisasi perpajakan, pelayanan fiskus dan pelaksanaan Self Assessment System untuk menguji kepatuhan wajib pajak kos dengan besarnya sumbangan faktor independen keseluruhan terhadap faktor dependen hanya sebesar $17,4 \%$.

\section{Saran}

Berdasarkan kesimpulan dan keterbatasan yang telah diuraikan, maka dapat diajukan saran-saran sebagai berikut.

1) Bagi Dinas Pendapatan Daerah Kota Malang

a) Bagi Dinas Pendapatan Daerah Kota Malang sebaiknya harus lebih giat dalam menerapkan upaya-upaya untuk meningkatkan kepatuhan wajib pajak seperti melakukan penyuluhan dan sosialisasi pajak kos kepada masyarakat dengan meningkatkan media sosialisasi yang digunakan.

b) Petugas Pajak diharapkan lebih memonitoring pelaksanaan Self Assessment System supaya dapat meningkatkan kepatuhan wajib pajak secara sukarela.

c) Merevisi tarif pajak atas pajak rumah kos ini menjadi tarif pajak progresif yang berdasarkan besarnya omzet yang telah ditetapkan supaya tercipta keadilan bagi pengusaha rumah kos.

2) Bagi Penelitian Selanjutnya

Penelitian selanjutnya diharapkan dapat meningkatkan nilai koefisien determinasi, dengan meneliti variabel lain yang berpengaruh terhadap kepatuhan wajib pajak.

\section{DAFTAR PUSTAKA}

- Peraturan Daerah Kota Malang Nomor 16 Tahun 2010 tentang pajak

Daerah. . Undang-Undang Nomor 28 Tahun 2009 tentang Pajak Daerah dan Retribusi Daerah. . Undang-Undang Nomor 32 Tahun 2004 tentang Pemerintahan Daerah.

- Keputusan Menteri keuangan No. 192/PMK.03/2007. . Undang -Undang Nomor 33 Tahun 2004 Tentang Perimbangan

Keuangan Pemerintah Pusat dan Pemerintah Daerah.

. Peraturan Daerah Nomor 6 Tahun 2006 tentang Usaha Pemondokan.

Ajzen, I. 1991. The Theory Of Planned Behavior, Organizasional Behavior And Human Decision Processes 50, 179-211. 
Ardiyanto, Arif Angga dan Nanik Sri Utaminingsih. 2014. Pengaruh Sanksi Pajak Dan Pelayanan Aparat Pajak Terhadap Kepatuhan Wajib Pajak Dengan Preferensi Risiko Sebagai Variabel Moderasi. Accounting AnalysisJournal AAJ, (Online). 3 (2):220-229,

(http://journal.unnes.ac.id), diakses 20 Agustus 2015.

Arikunto, Suharsimi. 2013. Prosedur Penelitian: Suatu Pendekatan Praktek.. Jakarta: PT. Rineka Cipta.

Aryobimo, Putut Tri dan Nur Cahyono. 2012. Pengaruh Persepsi Wajib Pajak tentang Kualitas Pelayanan Fiskus Terhadap Kepatuhan Wajib Pajak dengan Kondisi Keuangan Wajib Pajak dan Preferensi Risiko sebagai Variabel Moderating (Studi Empiris terhadap Wajib Pajak Orang Pribadi di Kota Semarang). Diponegoro Jurnal Of Accounting, (Online), 1 (2):1-12, (http://ejournal-s1.undip.ac.id), diakses 20 Agustus 2015.

Bawono, Icuk Rangga \& Mochamad N. 2012. Tata Cara Penatausahaan Dan Pertanggungjawaban Bendahara Pada Skpd Dan Skpkd( Pemerintah Daerah Kabupaten/Kota Dan Provinsi). Jakarta:Salemba Empat.

Buku saku Perpajakan Pemilik Indekos. (Online), (http://pajak.go.id), diakses 12 Sepetember 2015.

Ghozali, Imam. 2009. Ekonometrika :Teori, Konsep dan Aplikasi Dengan SPSS 17. Semarang. Badan Penerbit Universitas Diponegoro.

Hardiningsih, Pancawati. 2011. FaktorFaktor yang Mempengaruhi Kemauan Membayar Pajak. Dinamika Keuangan dan Perbankan, (Online), 3 (1):126-142,

(http://www.unisbank.ac.id), diakses 20 Agustus 2015.

Hartono, Jogiyanto. 2011. Metodologi Penelitian.Yogyakarta:BPFE

Judisseno, Rimsky K. 2005. Pajak dan Strategi Bisnis. Jakarta:PT Gramedia Pustaka Utama.
Mardiasmo. $2011 . \quad$ Perpajakan. Yogyakarta:Andi

Morisson, dkk. 2012. Metode Penelitian Survey. Jakarta: Prenada Media Grup. Murti, Hangga Wicaksono, dkk. 2014. Pelayanan Fiskus dan Pengetahuan Perpajakan Terhadap Kepatuhan Wajib Pajak Orang Pribadi di Kota Manado. Jurnal EMBA 389, (Online), 2

(3):389-398, (http://ejournal.unsrat.ac.id), diakses 20 Agustus 2015.

Mustikasari, Elia. 2007. Kajian Empiris Tentang Kepatuhan Wajib Pajak Badan di Perusahaan Industri Pengolahan di Surabaya. Simposium Nasional Akuntansi X ASPP-16.

Prabowo, Agung Dwi. 2015. Efektivitas Sosialisasi Perpajakan Terhadap Kepatuhan Pelaporan SPT Tahunan Wajib Pajak Orang Pribadi Pada Kantor Pelayanan, Penyuluhan, dan Konsultasi Perpajakan (KP2KP) Tondano. Jurnal EMBA, (Online), 3 (1):1063-1070,

(http://ejournal.unsrat.ac.id), diakses 20 Agustus 2015.

Rahayu. 2010. Perpajakan Indonesia-Konsep dan Aspek Formal. Graha Ilmu, Yogyakarta.

Resmi, Siti. 2008. Perpajakan : Teori dan Kasus Edisi ke-4. Jakarta: Salemba Empat.

Santoso, Singgih. 2007. Statistik Deskriptif "Konsep dan Aplikasi dengan Microsoft Excel dan SPSS.Yogyakarta:Andi.

Sari, Diana. 2013. Konsep Dasar Perpajakan. Bandung: PT. Refika Aditama.

Sekaran, Umar.2009. Metodologi Penelitian Untuk Bisnis. Jakarta : Salemba Empat.

Setiawan, Setu \& Eny Suprapti. 2002. Perpajakan. Malang:UMM PRESS.

Setiawan, Wahyudi dan Ahsin Daroni. 2013. Pengaruh Sosialisasi Dan Bank Tempat Pembayaran Terhadap Kepatuhan Wajib Pajak Dalam Membayar Pajak Bumi Dan Bangunan di Kabupaten Nganjuk. Jurnal Ilmu Manajemen REVITALISASI, (Online), 
2 (3):45-57, (http://pascauniskakediri.ac.id), diakses 20 Agustus 2015.

Setyoningrum, Try, dkk. 2014. Analisis Pengaruh Sosialisasi Perpajakan, Kualitas Pelayanan Fiskus dan Sanksi Perpajakan Terhadap Kepatuhan Wajib Pajak Orang Pribadi Di Kantor Pelayanan Pajak Pratama Manado. Jurnal Riset Akuntansi Going Concern, (Online), 9 (4): 53-65, (http://ejournal.unsrat.ac.id), diakses 20 Agustus 2015.

Simanjuntak, Timbul H \& Imam Muklis. 2012. Dimensi Ekonomi Perpajakan dalam Pembangunan Ekonomi. Depok:Raih Asa Sukses.

Singarimbun, Masri \& Sofian Efendi. 1995. Metode Penelitian Survai. Jakarta:PT Pustaka LP3ES Indonesia.

Sugiyono. 2010. Metode Penelitian Pendidikan. Bandung:Alfabeta.

Sugiyono. 2011. Statistika untuk Penelitian. Bandung: Alfabeta.

Suharso, Puguh. 2010. Model Analisis Kuantitatif "TEV". Jakarta : Indeks.

Sukandarrumidi. 2012. Metodologi Penelitian Gajah Mada. Yogyakarta:Gajah Mada University Press.

Surantono, Bambang. 2003. Pajak-Pajak Indonesia Tahun 2003. Malang:Universitas Negeri Malang (UM PRESS).

Trisnayanti, Ida Ayu Ivon dan I Ketut Jati. 2015. Pengaruh Self Assessment System, Pemeriksaan Pajak, dan Penagihan Pajak Pada Penerimaan Pajak Pertambahan Nilai (PPN). ISSN :2302-8556 E-Jurnal Akuntansi Universitas Udayana, (Online), 13 (1):292-310, (http://ojs.unud.ac.id), diakses 20 Agustus 2015.

Wibowo. 2014. Perilaku dalam Organisasi. Depok: PT. Rajagrafindo Persada.

Widodo, Widi, dkk. 2010. Moralitas, Budaya, dan Pajak.Bandung:Alfabeta

Kepatuhan

Winerungan, Oktaviane Lidya. 2013. Sosialisasi Perpajakan, Pelayanan Fiskus dan Sanksi Perpajakan Terhadap Kepatuhan Wpop Di Kpp Manado Dan Kpp Bitung. Jurnal EMBA, (Online), 1 (3):960-970,

(http:/ / download.portalgaruda.org), diakses 20 Agustus 2015.

Yani, Ahmad. 2008. Hubungan Keuangan Antara Pemerintah Pusat dan Daerah di Indonesia. Jakarta:PT Rajagrafindo Persada.

Yeyen, NuroctaViani Rumi \& Y. Agus Bagus Budi. 2012. Pengaruh Kualitas Layanan Terhadap Kepatuhan Membayar Wajib Pajak (Studi Pada Kantor Pelayanan Pajak di Jakarta Kelapa Gading . Jurnal Informasi, Perpajakan, Akuntansi dan Keuangan Publik, (Online), 7 (1):61-72, (http://www.online.fe.trisakti.ac.id), diakses 20 Agustus 2015.

Zuraida, ida. 2012. Teknik Penyusunan Peraturan Daerah. Jakarta:Sinar Grafika.

dispenda.malangkota.go.id dispendukcapil.malangkota.go 
JURNAL NOMINAL / VOLUME V NOMOR 1 / TAHUN 2016 